\title{
Pengembangan pola berpikir sistematis melalui pengenalan pemrograman visual pada peserta didik tingkat menengah atas
}

\author{
Robby Tan ${ }^{1}$, Maresha Caroline Wijanto ${ }^{1}$, Oscar Karnalim ${ }^{1}$, Setia Budi ${ }^{2}$, Mewati Ayub ${ }^{2}$, \\ Diana Trivena Yulianti ${ }^{3}$, Hendra Bunyamin ${ }^{1}$, Sendy Ferdian Sujadi ${ }^{3}$, Rossevine Artha \\ Nathasya ${ }^{1}$
}

\begin{abstract}
Systematic thinking is a process of thinking that should be introduced from early age. While developing such thinking, students will learn how to solve a task by breaking it down to smaller tasks and complete them one by one. There are many activities that can support such thinking. One of them is to program visually. Visual programming is usually featured with drop-down blocks where students are only required to choose which process or logic needed than then put them in the play board. A training of such activity was done in a high school at Bandung, Indonesia with Scratch. Students were first introduced with Scratch, a software that is expected to help them think systematically. For conducting the training itself, several stages were followed. It started with introduction, and then followed by lecture and case-based practice. To engage students with the practice, the case study is COVID-19 where students are expected to deliver relevant information creatively, such as developing a game of social distancing, spray vs virus, etc. Evaluation shows that via this training, students were able to further develop their own systematic thinking via the creation of Scratch projects. Further, they believed that this training is interesting and can help them to study in the high school.
\end{abstract}

\section{Keywords}

Computational thinking, pemrograman visual, pola berpikir sistematis, scratch

\section{Pendahuluan}

Sejak tahun 2019, dunia dikejutkan dengan pandemi yang mempengaruhi aspek kehidupan. Salah satu aspek yang mengalami dampak cukup besar adalah pendidikan, di mana proses pembelajaran tatap muka (PTM) digantikan menjadi pembelajaran jarak jauh (PJJ). Dengan menggunakan konsep PJJ, maka semua media komunikasi menggunakan internet dan tatap muka dilakukan secara maya. Konsep PJJ ini akan mempengaruhi jalan kurikulum yang akan atau telah disusun karena pengajar perlu mempersiapkan proses pengajaran yang baru namun tetap memenuhi standar kurikulum yang ada.

Kurikulum merupakan bagian inti dari proses pembelajaran yang dilaksanakan oleh unit pendidikan. Dengan memiliki kurikulum yang tepat dan terarah, peserta didik dibentuk dan dididik agar tidak hanya memiliki hardskill namun juga soft-skill. Kurikulum 2013 yang saat ini diimplementasikan di sekolah-sekolah sudah memiliki metode pembelajaran secara tematik. Menurut Iskandar dkk., konsep pembelajaran tematik yang diusung dalam pendidikan di Indonesia akan memadukan kompetensi dasar dan satuan isi dalam tema-tema khusus. Harapan dari pembelajaran tematik ini agar peserta didik mampu mengaitkan ilmu dan keterampilan pada setiap mata pelajaran sehingga memperoleh gambaran ilmu secara utuh (Iskandar et al., 2019).

Dalam pelaksanaan Kurikulum 2013, mata pelajaran Teknologi Informasi dan Komputer (TIK) dihilangkan kemudian dimunculkan kembali dalam bentuk mata pelajaran tidak wajib atau mata pelajaran tambahan. Dengan perubahan tersebut, maka mata pelajaran TIK tidak mendapat atensi khusus dari sekolah maupun guru sehingga tidak memiliki materi atau silabus terstruktur yang dapat menunjang pengembangan logika maupun kemampuan TIK peserta didik (Muharika \& Fitria, 2019). Berkurangnya atensi tersebut akan membawa dampak bagi

Program Studi S1 Teknik Informatika, Fakultas Teknologi Informasi, Universitas Kristen Maranatha ${ }^{2}$ Program Studi Magister Ilmu Komputer, Fakultas Teknologi Informasi, Universitas Kristen Maranatha ${ }^{3}$ Program Studi S1 Sistem Informasi, Fakultas Teknologi Informasi, Universitas Kristen Maranatha

Korespondensi:

Robby Tan, Fakultas Teknologi Informasi, Universitas Kristen Maranatha

Email: robby.tan@it.maranatha.edu 
perkembangan dan pemahaman peserta didik mengenai pentingnya teknologi informasi.

Fakultas Teknologi Informasi (FTI) Universitas Kristen Maranatha berupaya agar pendidikan pada bidang TIK dapat terus dipupuk di sekolah-sekolah. Cara-cara yang ditempuh adalah melalui kegiatan pengabdian kepada masyarakat serta terjun sebagai salah satu biro Bebras di Indonesia (Ayub et al., 2017). Bebras merupakan sebuah organisasi yang mempromosikan computational thinking di kalangan guru dan siswa (Bebras Indonesia, 2021). Kegiatan pengabdian kepada masyarakat yang dilakukan selalu memasukkan materi mengenai informatika yang dikolaborasikan dengan mata pelajaran tertentu. Di masa pelaksanaan pembelajaran jarak jauh (PJJ), terdapat beberapa tantangan yang dihadapi antara lain seperti koneksi internet, berkurangnya interaksi antara fasilitator dan peserta didik, dan kesulitan dalam pembelajaran secara mandiri (Karnalim \& Wijanto, 2021; Wijanto et al., 2021a). Dengan tantangan tersebut, FTI tetap berupaya agar proses pengabdian masyarakat tidak hilang dengan melakukannya secara daring sehingga peserta didik tetap mendapatkan materi mengenai informatika.

Pemrograman visual memungkinkan pembelajaran pola pikir sistematis melalui proses pemrograman namun dengan menekan tantangan-tantangan umum yang muncul di pemrograman seperti kesalahan tulis. Pelajar hanya perlu memilih blok sintaks tertentu ketimbang menuliskannya dari nol. Scratch (Resnick et al., 2009), Alice (Cooper et al., 2000), dan Greenfoot (Kölling, 2010) adalah contoh kakas pembelajaran yang mendukung pemrograman visual. Kategori kakas lain yang dapat membantu pembelajaran pola pikir sistematis melalui pemrograman adalah visualisasi program. Kakas jenis ini memungkinkan pelajar untuk mengerti bagaimana program mereka berjalan secara umum. Beberapa contoh kakas untuk kategori ini adalah Jeliot 3 (Moreno et al., 2004), Python Tutor (Guo, 2013), dan DS-PITON (Nathasya et al., 2019).

Fokus materi informatika selama kegiatan adalah memberikan pemahaman mengenai logika dalam sebuah studi kasus (problem solving). Studi kasus yang diangkat berkisar seputar kehidupan dari peserta didik atau informasi umum. Peserta didik diajak untuk bersama-sama berpikir secara rasional dengan menggunakan perangkat yang tersedia untuk mendesain sebuah solusi (Dagiene \& Stupuriene, 2016). Materi informatika yang disampaikan bukan dalam bentuk menulis kode program menggunakan bahasa pemrograman tertentu, namun dalam bentuk pemecahan masalah secara komputasi (computational thinking) yang dituangkan dalam sebuah solusi visual menggunakan blok pemrograman visual.

\section{Metode}

Sebelum dilaksanakannya kegiatan kepada masyarakat, FTI mengadakan briefing dengan pihak sekolah untuk

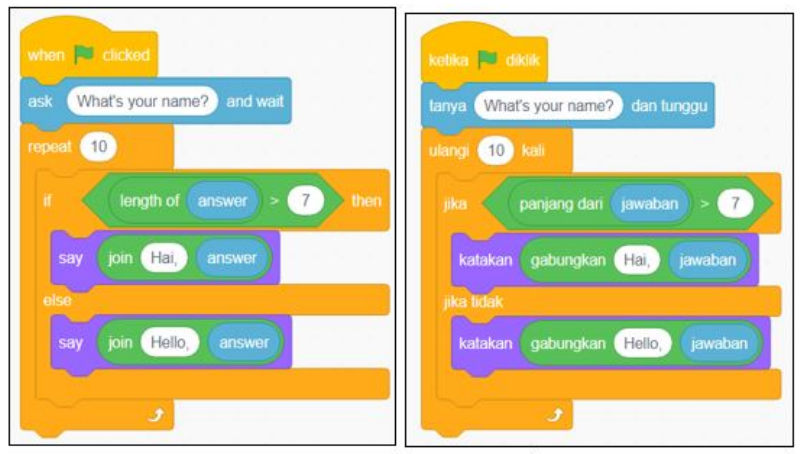

Gambar 1. Contoh Pemrograman Blok Menggunakan Scratch

menentukan topik serta materi informatika yang akan disampaikan (Gambar 1). Dari hasil keputusan tersebut, disepakati bahwa materi mengenai pemrograman visual yang melibatkan computational thinking yang akan dibagikan kepada peserta didik. Selain dari menentukan materi, dilakukan diskusi mengenai tema yang dijadikan sebagai tugas kelompok agar peserta didik dapat berkolaborasi dan memahami materi yang diberikan.

Kemampuan peserta didik dalam memecahkan sebuah masalah (problem solving) perlu dikembangkan melalui aktivitas yang melibatkan logika. Aktivitas yang dilakukan dapat berbentuk computational thinking dengan menggunakan pemrograman blok (Wijanto et al., 2021b). Pemrograman blok merupakan salah satu solusi yang dapat digunakan agar peserta didik terbiasa berpikir secara komputasi, tidak dipusingkan dengan sintak pemrograman, dan hasilnya dapat langsung terlihat (visual). Beberapa contoh dari pemrograman blok adalah Scratch dan Blockly.

Scratch merupakan sebuah kakas berbasis daring yang didesain oleh sebuah organisasi nonprofit yaitu Scratch Foundation. Dalam proses pembuatan, pengguna dapat melakukan drag and drop objek-objek yang disediakan dan menyusunnya menjadi sebuah bagian atau disebut dengan blok (Scratch Team, 2021). Scratch dibuat dengan tujuan mengenalkan logika proses tanpa harus menggunakan kode program dalam bahasa tertentu. Zhang dan Nouri mengemukakan bahwa Scratch dapat membantu peserta didik untuk mengembangkan pola berpikir secara komputasi (computational thinking) (Zhang \& Nouri, 2019). Scratch dipilih untuk kegiatan pengabdian ini dibandingkan dengan kakas pemrograman blok lainnya karena Scratch sering digunakan dalam pengenalan logika secara visual. Scratch juga tersedia secara daring dan tersedia dalam bahasa lokal.

Beberapa materi dasar yang tercakup dalam mata kuliah bidang pemrograman antara lain materi mengenai input-output, variabel, percabangan, dan pengulangan. Materi-materi tersebut dikemas dalam Scratch sehingga peserta didik dapat dengan mudah menggunakannya karena disampaikan dalam bahasa sehari-hari. Dengan menggunakan bahasa ibu dan bahasa yang digunakan 


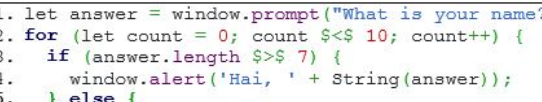

Gambar 2. Contoh Translasi dari Visual ke Kode menggunakan JavaScript

sehari-hari, penyerapan konsep pemrograman jauh lebih cepat dibandingkan penggunaan bahasa umum yaitu Inggris (Dasgupta \& Hill, 2017). Gambar 1 merupakan contoh sederhana pemrograman blok dalam Scratch di mana dalam blok tersebut terdapat konsep mengenai input-output, variabel, percabangan, dan pengulangan. Dengan menggunakan bahasa lokal (dalam studi kasus ini adalah bahasa Indonesia), maka peserta didik lebih mudah untuk mengetahui makna dari blok yang digunakan dan menggabungkannya secara visual.

Pemrograman visual secara mudah akan lebih menjelaskan proses logika yang terjadi untuk sebuah urutan kejadian (Idrees et al., 2018). Jika digambarkan dalam kode program, maka hasil translasi dapat dituliskan menggunakan bahasa pemrograman (Gambar 2). Pada tahapan ini, kita dapat melihat bahwa dengan menggunakan pemrograman blok yang dapat dilihat secara visual, peserta didik tidak perlu menuliskan kode program dalam bahasa pemrograman tertentu namun dapat menghasilkan sebuah algoritma proses yang sama.

Pengabdian kepada masyarakat dilakukan dalam beberapa tahap yaitu persiapan materi, pelaksanaan kegiatan training for trainers (TFT), pelaksanaan kegiatan pengabdian, dan melakukan evaluasi kegiatan. Tahapan persiapan dilakukan dengan diskusi secara daring dengan pihak sekolah terkait topik dan tema yang akan digunakan sebagai hasil kreativitas peserta didik. Selain itu, dibahas juga mengenai teknik pelaksanaan kegiatan yang akan dilakukan. Pada tahapan ini telah disetujui bahwa untuk materi pemrograman visual menggunakan Scratch akan disampaikan ke peserta didik kelas $\mathrm{X}$.

Pelaksanaan kegiatan diawali dengan penyampaian materi mengenai logika yang dilanjutkan dengan pengenalan perangkat lunak yang digunakan. Penyampaian materi dilakukan secara daring menggunakan Microsoft Team. Kakas yang digunakan untuk menjelaskan logika proses berpikir adalah Scratch yang dapat diakses pada tautan https://scratch.mit.edu. Demonstrasi mengenai Scratch dilakukan oleh fasilitator dengan sistem project-based sehingga peserta didik dapat mengikuti dan menerapkan materi pada perangkat yang digunakan. Setelah penyampaian materi selesai, peserta didik diberikan sebuah instruksi untuk mengembangkan materi yang disampaikan dalam bentuk sebuah proyek dengan tema COVID-19. Proyek tersebut akan dibuat secara berkelompok sehingga para peserta didik dapat berkolaborasi dan bekerja sama dalam tim sehingga dapat saling memberikan atau mendiskusikan ide atau cara penempatan blok.

\section{Hasil dan Luaran}

Pelaksanaan kegiatan pengabdian dilakukan dalam beberapa tahapan mulai dari persiapan, pelatihan fasilitator (TFT), pelaksanaan kegiatan, dan evaluasi. Seluruh kegiatan tersebut dilakukan secara daring mengingat masih tingginya potensi penyebaran virus. Kegiatan pengabdian kepada masyarakat dilakukan di SMA St. Angela Bandung pada tanggal 9 dan 10 September 2021. Kegiatan tersebut diikuti oleh 7 kelas peserta didik kelas $\mathrm{X}$ dengan ratarata jumlah peserta didik masing-masing kelas adalah 30 orang. Proses penyampaian materi dipandu oleh tujuh (7) orang fasilitator yang merupakan dosen Fakultas Teknologi Informasi dibantu tujuh (7) orang asisten. Masing-masing fasilitator dan asisten akan bertanggung jawab untuk satu kelas.

Materi Scratch disampaikan dalam bentuk sebuah proyek dengan tema Meet and Greet. Peserta didik akan dipandu oleh fasilitator masing-masing kelas dalam membuat proyek yang sama kemudian dilanjutkan dengan pembuatan proyek mandiri secara berkelompok. Setiap kelompok diberikan kebebasan dalam menyusun ide dan proses yang diperlukan selama memenuhi tema yang diberikan beserta dengan beberapa syarat proyek. Syarat-syarat ini menjadi batasan yang diperlukan agar peserta didik belajar memahami konsep logika dengan menggunakan computational thinking (Zhang \& Nouri, 2019).

Pada akhir sesi, setiap kelompok peserta didik akan melakukan presentasi atas ide dan kreativitas yang telah dituangkan dalam pembuatan proyek Scratch mengenai COVID-19. Setiap kelompok akan memaparkan ide dan hasil yang telah dicapai selama pengembangan proyek beserta dengan kesulitan-kesulitan yang dihadapi. Berikut ini terdapat beberapa contoh dari pengembangan dan presentasi Scratch yang dikemas dengan ide-ide kreatif peserta didik.

Salah satu proyek dari peserta berjudul "Gunakan Masker". Disitu, peserta didik menanamkan pengertian bahwa saat ini di sekitar kita masih banyak virus. Dengan menggunakan masker, kita dapat terhindar dari bahaya virus yang masuk ke dalam saluran pernafasan. Pengguna dapat berinteraksi pada proyek tersebut dengan melakukan klik pada orang yang terdapat pada play board. Jika terdapat salah satu orang yang melepaskan masker, maka secara otomatis virus-virus yang berada di udara akan menyerang orang tersebut. Ide dan pesan yang ingin disampaikan dalam proyek ini adalah selalu menggunakan masker dengan cara yang benar.

Selain proyek di atas, peserta lain menghasilkan proyek dengan tema "Spray Vs Virus". Proyek yang dipresentasikan ini mengambil ide dari cairan yang digunakan untuk mematikan virus. Cara penyampaian ide dari kelompok ini menarik karena menggunakan konsep gamifikasi sebagai solusinya sehingga pengguna tidak cepat merasa bosan. Gamifikasi yang diusung dalam proyek ini adalah menggunakan simulasi cairan pembersih 


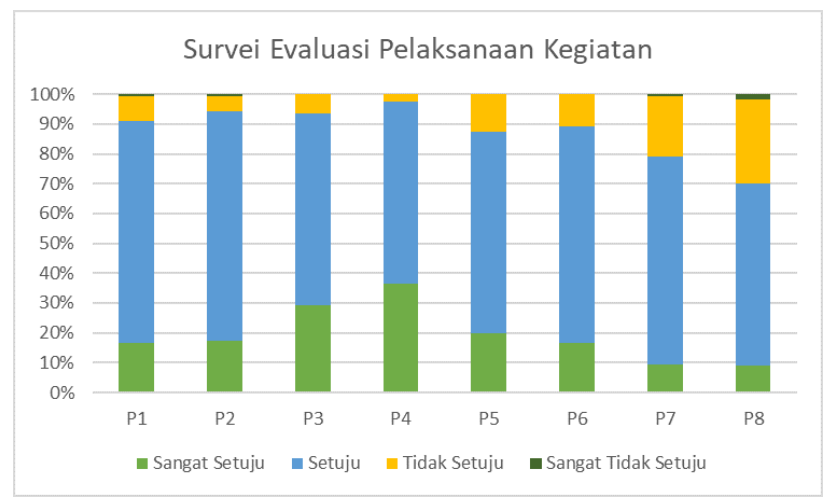

Gambar 3. Hasil Survei Pelaksanaan Kegiatan

(dimodelkan dengan pesawat) dan virus. Pemain dapat menggunakan pesawat untuk menghancurkan virus dan setiap virus yang dihancurkan akan dikonversi menjadi poin.

Setiap hasil kreativitas kelompok peserta didik yang dipresentasikan akan mendapatkan nilai. Fasilitator akan menilai berdasarkan kriteria proyek yang diberikan, ide yang diusung, dan kekompleksan dari blok-blok yang membentuk jalannya cerita. Fasilitator akan menentukan kelompok yang mendapatkan nilai tertinggi dari masingmasing kelas sehingga terkumpul tujuh (7) karya terbaik. Tujuh kelompok ini akan mendapatkan apresiasi atas kerja keras dan kreativitas sehingga kiranya dapat memacu peserta didik belajar dengan lebih baik.

Secara umum, fasilitator merasa kemampuan siswa untuk berpikir sistematis cukup baik. Mereka berhasil menyelesaikan proyek Scratch mereka dan mampu menggunakan beragam fitur dan logika yang menarik.

Setelah sesi presentasi, kami juga melakukan survei kepada peserta didik atas kegiatan yang dilaksanakan. Survei ini bertujuan sebagai refleksi atas kegiatan, materi, dan interaksi yang dapat menjadi bahan evaluasi di kegiatan-kegiatan berikutnya. Terdapat delapan (8) pertanyaan (P1-P8) yang diajukan kepada peserta didik dengan hasilnya sebagai berikut.

Hasil survei menyatakan bahwa mayoritas peserta didik $(87,74 \%)$ memberikan respons yang baik mengenai kegiatan yang dilaksanakan. Sebanyak 87,26\% peserta didik menyatakan bahwa materi yang disampaikan menarik (P5) dan 89,17\% peserta didik menyatakan bahwa materi yang disampaikan dapat berguna dalam proses pembelajaran di SMA (P6). Hal ini menyatakan bahwa secara keseluruhan materi dapat diterima dan dapat menunjang proses pembelajaran di SMA dengan mengembangkan pola berpikir sistematis melalui pemrograman visual dengan Scratch.

\section{Kesimpulan}

Dapat ditarik simpulan dari kegiatan pengabdian kepada masyarakat mengenai pengembangan pola berpikir sistematis melalui pengenalan pemrograman visual pada peserta didik tingkat menengah atas yaitu: (1) Pelatihan pengembangan pola berpikir sistematis yang dilaksanakan di salah satu sekolah menengah tingkat atas di Kota Bandung pada bulan September 2021 berhasil dilaksanakan secara daring dipandu oleh tujuh orang fasilitator dan tujuh orang asisten. (2) Materi Scratch yang diberikan menarik dan membawa dampak positif untuk proses pembelajaran selama menempuh pendidikan di sekolah menengah tingkat atas. (3) Pemberian materi disertai dengan sesi pembuatan proyek mandiri dapat menunjang kreativitas dan kolaborasi peserta didik dalam proses pembelajaran.

\section{Referensi}

Ayub, M., Wijanto, M. C., Senjaya, W. F., Karnalim, O., Kandaga, T., Witono, T., Gantini, T. (2017). Edukasi Berpikir Komputasional melalui Pelatihan Guru dan Tantangan Bebreas untuk Siswa di Bandung pada Tahun 2016. Seminar Nasional Pengabdian Kepada Masyarat (Sendimas). Bandung.

Bebras Indonesia. (2021, Oktober 5). Apa Itu Bebras. Diambil kembali dari Situs Resmi Bebras Indonesia: https://bebras. or.id/v3/apa-itu-bebras/

Cooper, S., Dann, W., \& Pausch, R. (2000). Alice: A 3-D Tool for Introcutory Programming Concepts. Journal of Computing Sciences in Colleges, 15(5), 107-116. doi:10.5555/364133. 364161

Dagiene, V., \& Stupuriene, G. (2016). Informatics Concepts and Computational Thinking in K-12 Education: A Lithuanian Persepective. Journal of Information Processing, 732-739. doi:10.2197/ipsjjip.24.732

Dasgupta, S., \& Hill, B. M. (2017). Learning to Code in Localized Programming Language. $L @ S$ '17: Proceeding of the Fourth (2017) ACM Conference on Learning @Scale (hal. 33-39). New York: Association for Computing Machinery. doi:10. 1145/3051457.3051464

Guo, P. J. (2013). Online Python Tutor: Embeddable Web-Based Program Visualization for CS Education. Proceeding of the 44th ACM Technical Symposium on Computer Science Education. New York: ACM Press. doi:10.1145/2445196. 2445368

Idrees, M., Aslam, F., Shahzad, K., \& Sarwar, S. M. (2018). Towards a Universal Framework for Visual Programming Languages. Pakistan Journal of Engineering and Applied Science, 55-65.

Iskandar, W., Azkia, N., \& Hasanah, H. (2019). Konsep Pembelajaran Tematik. Yogyakarta: K-Media.

Karnalim, O., \& Wijanto, M. C. (2021). Transitioning to Online Learning for Indonesian High School Students: Challenges and Possible Solutions. 2021 International Conference on Advanced Learning Technologies (ICALT), (hal. 428-430). doi:10.1109/ICALT52272.2921.99136

Kölling, M. (2010). The Greenfoot Programming Environment. ACM Transactions on Computing Educations, 10(4), 14:114:21. doi:10.1145/1868358.1868361

Moreno, A., Myller, N., Sutinen, E., \& Ben-Ari, M. (2004). Visualizing Programs with Jeliot 3. Proceedings of the 
Working Conference on Advanced Visual Interfaces, (hal. 373-376). New York. doi:10.1145/989863.989928

Muharika, D., \& Fitria, R. A. (2019). Kebutuhan Pengembangan Modul Bimbingan Teknologi Informasi dan Komunikasi (TIK) Terintegrasi Literasi Baru Era Revolusi Industri 4.0. Jurnal PTI (Pendidikan Teknologi Informasi), 6(1), 80-86. doi:10.35134/jpti

Nathasya, R. A., Karnalim, O., \& Ayub, M. (2019). Integrating Program and Algorithm Visualisation for Learning Data Structure Implementation. Egyptian Informatics Journal, 193-204. doi:10.1016/j.eij.2019.05.001

Resnick, M., Maloney, J., Monroy-Hernándes, A., Rusk, N., Eastmond, E., Brennan, K., Kafai, Y. (2009). Scratch: Programming for All. Communcations of the ACM, 52(11), 60-67. doi:10.1145/1592761.1592779

Scratch Team. (2021, 09 22). About Scratch. Diambil kembali dari https://scratch.mit.edu/about

Wijanto, M. C., Karnalim, O., Ayub, M., Toba, H., \& Tan, R. (2021). Transitioning from Offline to Online Learning: Issue from Computer Student Perspective. IEEE Global Engineering Education Conference (EDUCON). Vienna. https://doi.org/10.1109/EDUCON46332.2021.9453996

Wijanto, M. C., Tan, R., Sujadi, S. F., Panca, B. S., Toba, H., Yulianti, D. T., Karnalim, O. (2021). Implementasi Computational Thinking Melalui Pemrograman Visual dengan Kolaborasi Mata Pelajaran pada Siswa Menengah Atas. Sendimas.

Zhang, L., \& Nouri, J. (2019). A Systematic Review of Learning Computational Thinking Through Scratch in K-9. Computers \& Educations, 141. Diambil kembali dari https://doi.org/10. 1016/j.compedu.2019.103607 